\title{
An unusual garlic burn occurring on an unexpected area
}

\author{
Ercan Karabacak, ${ }^{1}$ Ersin Aydın, ${ }^{2}$ Ali Kutlu, ${ }^{3}$ Bilal Dogan ${ }^{1}$
}

${ }^{1}$ Department of Dermatology, Gulhane Military Medical Academy Haydarpasa Teaching Hospital, Istanbul, Turkey ${ }^{2}$ Department of Dermatology, Kasımpasa Military Hospital, stanbul, Turkey ${ }^{3}$ Department of Allergy, Gulhane Military Medical Academy Haydarpasa Teaching Hospital, Istanbul, Turkey

\section{Correspondence to}

Dr Ercan Karabacak,

ekarabacak@gata.edu.tr

Accepted 10 March 2014

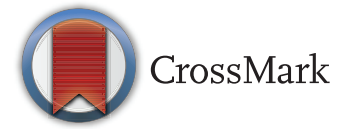

To cite: Karabacak $\mathrm{E}$, Aydın E, Kutlu A, et al. BMJ Case Rep Published online: [please include Day Month Year] doi:10.1136/bcr-2013203285

\section{DESCRIPTION}

A 24-year-old otherwise healthy woman presented with an itchy, burning, erythematous lesion located over her neck. She had applied crushed raw garlic over her neck for about $5 \mathrm{~h}$ following a sore throat. On dermatological examination an erythematous demarcated area with eruption, patchy squamous and vesicular lesions were present over the submandibular region (figure 1). On the basis of history and clinical examination, the patient was diagnosed with garlic burn.

Garlic (Allium sativum) has traditionally been used for several disorders since 3000 BC. Applying crushed garlic bulbs to the site of pain with a bandage is still a frequent routine to sooth local pain in eastern cultures. ${ }^{1}$ Its application over the neck, however, is an extremely rare condition.

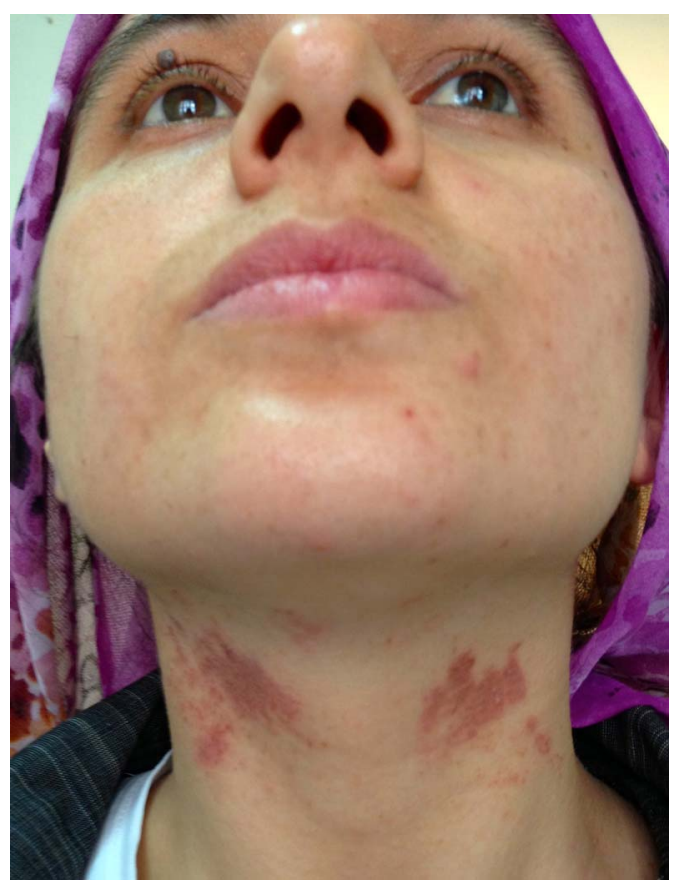

Figure 1 Erythematous, patchy squamous and vesicular lesions over the submandibular region.
Depending on the concentration, freshness, duration of exposure, anatomic area of application and individual reactivity, garlic application may either lead to contact dermatitis (erythema and blisters) or may occasionally cause a deeper 'chemical' burn ${ }^{2}$ as was the case in our patient. The treatment of garlic-related burns involves the use of topical antibiotics, steroid ointments and cool compress application. ${ }^{3}$

The lesions totally healed within 1 week of combined therapy with topical antibiotic, steroid and antihistaminic ointments. Clinicians should enquire about naturopathic medicines when obtaining medical history and should be aware of the possible adverse side effects or interactions related to their usage.

\section{Learning points}

- Searching naturopathic remedy with fibrinolytic activity among patients, with the clinic, of contact dermatitis or chemical burns may provide valuable contributions.

- Garlic is a commonly used naturopathic remedy but patients should be informed about its misuse complications.

- Clinicians should enquire about naturopathic medicines when obtaining medical history.

\section{Competing interests None.}

Patient consent Obtained.

Provenance and peer review Not commissioned; externally peer reviewed.

\section{REFERENCES}

1 Al-Qattan MM. Garlic burns: case reports with an emphasis on associated and underlying pathology. Burns 2009;35:300-2.

2 Dietz DM, Varcelotti JR, Stahlfeld KR. Garlic burns: a not-so-rare complication of a naturopathic remedy? Burns 2004;30:612-13.

3 Friedman T, Shalom A, Westreich M. Self inflicted garlic burns: our experience and literature review. Int J Dermatol 2006;45;1161-3.

\footnotetext{
Copyright 2014 BMJ Publishing Group. All rights reserved. For permission to reuse any of this content visit http://group.bmj.com/group/rights-licensing/permissions.

BMJ Case Report Fellows may re-use this article for personal use and teaching without any further permission.

Become a Fellow of BMJ Case Reports today and you can:

- Submit as many cases as you like

- Enjoy fast sympathetic peer review and rapid publication of accepted articles

- Access all the published articles

- Re-use any of the published material for personal use and teaching without further permission

For information on Institutional Fellowships contact consortiasales@bmjgroup.com

Visit casereports.bmj.com for more articles like this and to become a Fellow
} 